\title{
Editorial
}

\section{Tudo bem, mas nada presta ou a lógica do "sem sentido"}

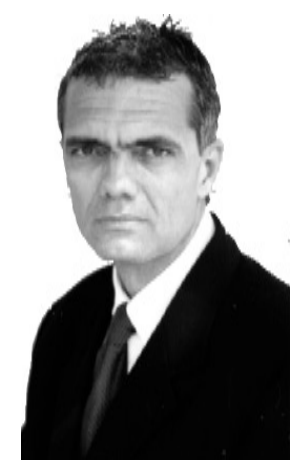

Marco Antonio Guimarães da Silva,Med.Dr.Sci. marco@atlanticaedu.com.br

O término de um curso de graduação ou de pós-graduação, a inserção no mercado de trabalho, o reconhecimento de nossa competência ou a conquista de algo que esperávamos nos trazem bons sentimentos. Não, necessariamente, vivemos felizes; entretanto, diante de algumas satisfações que incorporamos ao nosso cotidiano, consideramo-nos pessoas felizes ou emocionalmente neutras. E assim podemos viver toda uma vida, levando...

Por outro lado, a dura realidade do contexto social, traduzida por uma violência urbana altamente exacerbada, por corrupções em todas as esferas, pelo des-trato da coisa pública, pelo descaso e incompetência dos políticos e governantes, deveria nos dar razões suficientes para anularmos qualquer motivo para sermos felizes ou mesmos para encararmos os fatos com neutralidade.

O sim de nossa aquiescência a um aparente ou real conforto, gerado por ações bem sucedidas no plano pessoal, e o não da recusa ou o imobilismo para criar e gerar ações públicas que detenham a quantidade de ações ruins, cometidas na sociedade em que vivemos, nos torna protagonistas de um cotidiano capaz de superar até mesmo o absurdo retratado nas peças teatrais de um Ionesco ou de um Becket.

Perdemos a capacidade de reflexão e vivemos em estado de verdadeira catatonia social, como rãs submetidas à intoxicação de um poderoso veneno neurotóxico de uma serpente; imobilizadas e à espera de serem digeridas pelas enzimas do vil réptil.

Perdemos, também, a capacidade de construir sistemas simbólicos ou sistemas de pensamento que possam subverter nossas necessidades básicas e criar necessidades não existentes na natureza. Restou-nos, apenas, a condição apresentada por qualquer animal, a de apossarmo-nos da realidade já existente e adaptarmo-nos à mesma para sobreviver. A nossa realidade acabou por enviar para a mais distante galáxia a idéia piagetiana construtivista da concepção da formação da inteligência e os correlatos substratos psicanalíticos para a construção do conhecimento.

A lógica é a ferramenta da coerência, e parece que, no presente caso, subvertemos a lógica ao aceitar a real contradição, acima citada, entre o plano pessoal e coletivo. Não temos coerência; logo, não possuímos lógica. $\mathrm{O}$ atomismo lógico (investigação lógica da realidade, defendida pelos filósofos do Círculo de Viena, especialmente Wittgenstein) não consegue oferecer substrato para entender tal situação, e tampouco a metafísica (que admite certos a priori da mente) também o consegue.

Nesse sentido, em um plano abstrato, podemos nos consolar com o texto de Lewis Carrol (Charles Dogson) - 18321898. Sua mais famosa obra - Alice no país das maravilhas - é um conto fantástico com direito a todos os personagens clássicos de contos infantis (caminhos inusitados, pílulas mágicas, animais falantes etc). Mas a importância de Alice resulta da dupla originalidade: a de ser um conto, em que o mais importante não é o que acontece, e sim o que se fala; um conto em que o autor-poeta é superado, ou melhor, auxiliado pelo professor-matemático, interessado na metalinguagem, que utiliza a transgressão lógica como uma terapia hipnótica. Alice pretende chegar à lógica por meio da incoerência e do absurdo. A obra de Carrol é uma excelente e lúdica iniciação ao mundo da lógica, através da demonstração de falácias, de contradições, de incongruências e paradoxos.

Lamentável saber que a obra que escrevemos diariamente, com as tintas das omissões e incoerências, só tem nos conduzido a uma única lógica: a lógica do sem sentido.

A esta altura, você, que conseguiu chegar ao fim desta leitura, deve estar se perguntando: mas que diabos tem a ver o tema levantado neste artigo com um periódico de fisioterapia ? Eu diria que nada tem a ver, que não faz sentido, que é totalmente ilógico.

Fazer sentido, ter lógica! É necessário? 